from the secretary-general, Dr. Robert S. Schwab, Massachusetts General Hospital, Boston 14, Mass.

\section{Fourth Anglo-American Aeronautical Conference}

THE Fourth Anglo-American Aeronautical Conference will be held in London during September 15-17. The subjects of papers to be discussed include the control of flight, structure of high-speed aircraft, fatigue of aeroplane structures, helicopter design, pod mounting of turbo-jet engines, boundary layer control, structural adhesives for metal aircraft, thermal de-icing, aerodynamics of compressor blade vibration, power plants for helicopters and delta aircraft. The Conference is open to members of the Institute of the Aeronautical Sciences, and members of the Royal Aeronautical Society, 4 Hamilton Place, London, W.1, from which further particulars can be obtained.

\section{Summer School of Physics}

TнE Italian Physical Society, under the auspices of the Ministry of Education and the National Research Council, is organizing an international school of physics, to be held at the Villa Monastero, Varenna, Lake Como, during August 19-September 12 under the direction of Prof. Giampietro Puppi, professor of theoretical physics in the University of Bologna. The subject to be considered will be problcms relating to the detection of elementary particles, with special reference to cosmic radiation, and the three individual topics and the respective lecturer will be as follows: the cloud-chamber method, Prof. P. M. S. Blackett (Imperial College of Science and Technology, London); nuclear emulsion method, Prof. C. F. Powell (University of Bristol); and primary cosmic radiation, Prof. H. Alfvén (Institute of Technology, Stockholm). All lectures and the accompanying seminars and discussions will be conducted in English or French. The school will be limited to $20-25$ persons. The fee, including full board, will be $30,000-35,000$ lire. Application forms should be sent before July 30 to Prof. G. Puppi, Societ à Italiana di Fisica, Via Saldini 50, Milan, Italy, from whom all further information can be obtained.

\section{Lectures by Members of the Everest Expedition}

THe Royal Geographical Society and the Alpine Club, by arrangement with Wilfred Van Wyck, are organizing twelve illustrated lectures on "The Ascent of Everest", to be given at the Royal Festival Hall, London, S.E.1, on the evenings of September 15, 16, $18,19,21,22,23$ and 28 , October 13 and November 2 , at 8 p.m., and on the afternoons of September 19 and October 10 at 3 p.m. The lectures will be by Colonel Sir John Hunt, leader of the Everest Expedition, Sir Edmund Hillary, A. Gregory, Major C. G. Wylie, W. G. Lowe, T. D. Bourdillon and C. W. F. Noyce. The proceeds from the lectures, and from those to be given in the provinces and abroad, will go to a trust fund for exploration in mountain regions. The first evening, September 15 , will be a gala event, for which further details will be announced in due course. Tickets for the lectures (prices 15s.3s. 6d.) will be on sale at the Royal Festival Hall and the usual agents as from July 27. Further information can be obtained from the Secretary of the Royal Geographical Society, 1 Kensington Gore, London, S.W.7.

\section{The Night Sky in August}

New moon occurs on August 9d. 16h. 10m., U.T., and full moon on August $24 \mathrm{~d} .20 \mathrm{~h} .2 \mathrm{~lm}$. The following conjunctions with the moon take place: August 5d. 03h., Jupiter $4^{\circ}$ S.; August 6d. 02h., Venus $5^{\circ}$ S.; August 8d. 02h., Mercury $3^{\circ}$ S.; August 15d. 1lh., Saturn $8^{\circ} \mathrm{N}$. In addition to these conjunctions with the moon, Mercury is in conjunction with Mars on August 23d. 14h. Mercury is too close to the sun to be seen during the early portion of the month, but towards the middle of the month it rises about $3 \mathrm{~h} .10 \mathrm{~m}$. and may be seen for a short time before sunrise, stellar magnitude $0 \cdot 1$; after this it approaches the sun and on August 31 rises only forty minutes before sunrise. Venus, a morning star, rises at $\mathbf{l h}$. $10 \mathrm{~m}$., 1h. $20 \mathrm{~m}$. and $1 \mathrm{~h} .50 \mathrm{~m}$. on August 1,15 and 31 , respectively; the visible portion of its illuminated disk varies between 0.67 and 0.78 , and its stellar magnitude averages $-3 \cdot 5$. Mars rises at about $3 \mathrm{~h}$. $40 \mathrm{~m}$. throughout August and is not well placed for observation, as it is rather close to the sun, until the end of the month when it rises more than an hour and a half before the sun; about August 9 it lies nearly midway between $\delta$ and $\gamma$ Cancris, but will not be easily seen at that time. Jupiter rises at $0 \mathrm{~h} .30 \mathrm{~m}$., $23 \mathrm{~h} .40 \mathrm{~m}$. and $22 \mathrm{~h} .50 \mathrm{~m}$. at the beginning, middle and end of the month, respectively, stellar magnitude about $-1 \cdot 8$; after the middle of the month it will be seen a little north of $\zeta$ Tauri, which it approaches during its slow easterly movement. Saturn sets at 22h. $15 \mathrm{~m}$., 21h. $20 \mathrm{~m}$. and 20h. $20 \mathrm{~m}$. on August 1 , 15 and 31, respectively, and lies about midway between $\alpha$ and $\zeta$ Virginis and a little east of $\theta$ Virginis. A partial eclipse of the sun, greatest magnitude $0 \cdot 372$, occurs on August 9, but is invisible at Greenwich. The Perseid meteor shower attains a maximum during August 10-12. Only one star brighter than magnitude 6 is occulted during the month, 49 Sgtr. disappearing on August 21d. 23h. 02.8m.

\section{Announcements}

The College of Physicians of Philadelphia has awarded the Alvarenga Prize for 1953 to Dr. F. D. Moore, surgeon-in-chief in the Peter Bent Brigham Hospital and Mosely professor of surgery in Harvard Medical School, for his outstanding contributions to knowledge of the changes in body metabolism following surgery. The Alvarenga Prize is an annual award established in 1883 by the late DaCosta Alvarenga, of Lisbon, Portugal, an associate fellow of the College.

THE following resignations have been announced from the University of Sheffield : Prof. E. J. Wayne, from the chair of pharmacology and therapeutics, on his appointment as regius professor in the practice of medicine in the University of Glasgow ; and Dr. H. J. Cowan, lecturer in civil engineering, on his appointment to the chair of architectural science in the University of Sydney. Mr. J. F. Fleming has been appointed lecturer in civil engineering in the University.

THE University of Padua is offering a Gabriella Zuccari scholarship of 300,000 lire for research of at least seven months duration at the Zoological Station, Naples, during 1954. The scholarship is open to any person who wishes to undertake research in zoology, comparative anatomy, physiology or embryology, and it may be renewed up to a maximum of three years. Application forms (to be returned by October 31) and further information can be obtained from the Secretariat of the University of Padua. 